\title{
DANA PENSIUN PENDORONG KESEJAHTERAAN PEKERJA DAN PENJAGA EKSISTENSI UMKM DALAM MENGHADAPI MASYARAKAT EKONOMI ASIA
}

Oleh:

\author{
Lokot Zein Nasution \\ Badan Kebijakan Fiskal, Kementerian Keuangan \\ Lokot.nasution@yahoo.com \\ Muhammad Khoirul Fuddin \\ Khoirul.fuddin@gmail.com \\ Fakultas Ekonomi dan Bisnis Universitas Muhammadiyah Malang
}

\begin{abstract}
This paper discusses the importance of pension fund which is a non-banking financial institution that has Perana in promoting economic growth and the welfare of workers in the retirement age and its benefits to eksistensu SMEs in the face of the Asean Economic Community (AEC). The purpose of this study to see the importance of the pension fund for workers during the later retirement age and the need for pension funds to the survival of SMEs in the face of the Asean Economic Community (AEC). The results explain that the role of pension funds are expected not just those given priority to the final target is to meet the needs of the current workforce entry age pension which is more widely used in the activities of a consumptive but expected the pension fund can be used not only by the participant retires but family members as well can be used for activities activities such as setting up operations without having to wait for the parties concerned entered the retirement age. So with demikan welfare pension fund participants and families will be more prosperous and productive. It is then hoped all companies or small-scale industry should have a medium or large and obliging each program tenagakerjanya have pension funds to avoid terjadniya mobilization of human resources to a foreign company at the time of entering the MEA 2015. With the increased prosperity that it offered by domestic perusaaahn one of them by giving progam pensions to workers expected the existence and well-being of the workforce will increase.
\end{abstract}

Keywords: MEA, SMEs, the Pension Fund

\begin{abstract}
ABSTRAK
Karya tulis ini membahas pentingnya dana pensiun yang merupakan lembaga keuangan non perbankan yang memiliki perana dalam meningkatkan pertumbuhan ekonomi dan kesejahteraan para tenaga kerja dalam memasuki usia pensiun serta manfaatnya terhadap eksistensu UMKM dalam menghadapi Masyarakat Ekonomi Asean (MEA). Tujuan dari penelitian ini untuk melihat pentingnya dana pensiun bagi tenaga kerja pada masa memasuki usia pensiun nantinya dan perlunya dana pensiun bagi keberlangsungan UMKM dalam menghadapi Masyarakat Ekonomi Asean (MEA). Hasil menjelaskan bahwa peranan dana pensiun diharapkan tidak saja hanya diprioritaskan kepada
\end{abstract}


sasaran akhir yaitu memenuhi kebutuhan para tenaga kerja saat masuk usia pensiun yang lebih banyak digunakan pada kegiatan yang bersifat konsumtif akan tetapi diharapkan dana pensiun dapat digunakan bukan saja oleh peserta pensiun akan tetapi anggota keluarga juga dapat menggunakan untuk kegiatan - kegiatan produktif seperti mendirikan usaha tanpa harus menunggu pihak bersangkutan masuk usia pensiun. Sehingga dengan demikan tingkat kesejahteraan para peserta dana pensiun dan keluarga akan lebih sejahtera dan produktif. Kemudian diharapkan seтиa perusahaan atau industri yang berskala kecil menengah atau besar harus memiliki dan mewajibkan setiap tenagakerjanya memiliki progam dana pensiun untuk menghindari terjadniya mobilisasi sumberdaya manusia kepada perusahaan asing pada saat memasuki MEA 2015. Dengan adanya peningkatan kesejahteraan yang ditawarakan oleh perusaaahn domestik salah satunya dengan pemberian progam dana pensiun kepada para tenaga kerja diharapkan eksistensi dan kesejahteraan para tenaga kerja akan meningkat.

Kata Kunci : MEA,UMKM, Dana Pensiun

\section{PENDAHULUAN}

Keberadaan dana pensiun di Indonesia bagi khalayak umum mungkin hanya akrab di telinga para aparatur negara atau biasa kita sebut dengan pegawai ngeri sipil (PNS) dan beberapa perusahaan yang berskala nasional atau multinasional, pernyataan ini merupakan stereotip yang sudah melekat di benak masyarakat Indonesia khususnya para pekerja. Kurang berkembangnya dana pensiun di Indonesia sebagian besar diakibatkan karena kurang begitu pahamnya masyarakat tentang dana pensiun. Keberadaan dana pensiun yang kurang begitu familiar ini pula yang menyebabkan bahwa pergerakan dana pensiun dirasa lemah dalam mendorong pertumbuhan ekonomi bangsa ketika dilihat dari peran lembaga keuangan non perbankan.

Tabel 1 : Penetrasi Asuransi 2011 - 2014

\begin{tabular}{l|r|r|r|r}
\multicolumn{1}{c}{ Uraian } & \multicolumn{1}{c}{2011} & \multicolumn{1}{c}{2012} & \multicolumn{1}{c}{2013} & \multicolumn{1}{c}{2014} \\
\hline GDP (triliun Rp.) & $7.427,10$ & $8.241,9$ & 9.084 & 10.010 \\
\hline $\begin{array}{l}\text { Premi Bruto (triliun } \\
\text { Rp.) }\end{array}$ & 153,13 & 175,89 & 193,06 & 214,43 \\
\hline Jumlah Penduduk (Juta) & 241 & 244 & 249 & 252 \\
\hline Penetrasi & $2,06 \%$ & $2,13 \%$ & $2,13 \%$ & $2,14 \%$ \\
\hline Densitas (ribu rupiah) & 638,39 & 720,86 & 775,99 & 850,91 \\
\hline
\end{tabular}

Sumber : TOR Call for Papaer LKNB 
Pada tabel tersebut, dapat dilihat bahwa sampai dengan bulan Desember 2014, tingkat penetrasi asuransi adalah $2,14 \%$, yang artinya premi asuransi memberikan kontribusi 2,14\% terhadap GDP. Selain itu, nilai densitas mencerminkan bahwa rata-rata pengeluaran setahun orang Indonesia untuk membayar premi asuransi adalah Rp850 ribu rupiah.

Apabila dilihat dari segi pengukuran tingkat kesejahteraan, dari sisi masyarakat yang bertindak sebagai pekerja, keberadaan dana pensiun akan sangat menunjang kesejahteraan dan pembukaan lapangan kerja baru bagi mereka para pekerja yang sudah memasuki usia pensiun. Sedangkan ketika melihat keberadaan dana pensiun bagi para pemilik perusahaan atau para produsen, dengan memperhatikan fungsi dana pensiun bagi para pekerjanya, maka sejatinya perusahaan terkait telah menunjukkan bahwa perusahaan tersebut merupakan perusahaan yang dapat memberikan tingkat kesejahteraan yang jauh lebih baik terhadap kehidupan para pekerjanya menjelang usia pensiun.

Implementasi penerapan dana pensiun di kalangan usaha mikro kecil menengah masih terasa minor. Para pekerja yang memiliki dana pensiun sebagian besar hanya terdapat di perusahaan besar yang biasanya berskala nasional dan perusahaan multinasional, sementara nasib para pekerja yang berada di perusahaan berskala kecil masih belum diperhatikan yang berkaitan dengan dana pensiun. Pergerakan yang lambat mengenai perkembangan dana pensiun sebenarnya bukan sepenuhnya tanggung jawab dari para pengelola dana pensiun saja akan tetapi juga terkait dengan kesadaran para masyarakat yang lebih khusus para pekerja. Kebanyakan para pekerja lebih memprioritas kenaikan gaji yang mereka harapkan setiap tahunnya akan tetapi mereka terkadang mengkesampingkan dana pensiun yang merupakan tabungan masa depan bagi setiap pekerja. 
Tujuan utama pekerja adalah untuk mencapai tingkat kesejahteraan yang optimal dan salah satu kendaraan utama untuk mencapai tingkat kesejahteraan yang optimal adalah dana pensiun. Para pekerja akan bergerak dan menuju kepada perusahaan yang mampu memberikan kesejahteraan yang maksimal. Dengan akan dibukanya Masyarakat Ekonomi Asia, maka sudah dapat dipastikan bahwa akan hadir beberapa perusahaan multinasional asing bertengger di Indonesia, hal ini merupakan titik rawan bagi eksistensi UKM yang terdapat di Indonesia. Tentu saja tidak berlebihan, permasalahan utama yang dihadapi UMKM tentu saja mengenai kemampuan daya saing dengan perusahaan asing sedangkan masalah berikutnya yang tidak kalah penting adalah dimungkinkan terjadi perpindahan para tenaga kerja ke perusahaan asing dimana sudah bukan rahasia umum bahwa biasanya perusahaan asing memberikan tingkat kesejahteraan yang tinggi dan tentu saja dengan berbagai progam dana pensiun yang sangat menggiurkan.
Roda

penggerakan pertumbuhan perekonomian bangsa berasal dari peran sentral UMKM yang tetap bertahan dalam badai krisis yang menerjang bangsa dalam beberapa tahun terakhir ini. Banyak dari pekerja UMKM yang sangat berjasa bagi pergerakan roda perekonomian bangsa, tetapi permasalahan umunya adalah walaupun UMKM berjasa dalam roda perekonomian hampir mayoritas pekerja UMKM kurang mendapatkan tingkat kesejahteraan yang maksimum seperti mengikuti progam pensiun. Mungkin yang menjadi alasan besar mengapa pekerja tetap bertahan dalam sektor UMKM waluapun dirasakan tidak memberikan kesejahteraan maksimum adalah tidak ada pilihan lain yang dapat mereka pilih, akan tetapi ini akan berbeda cerita nantinya jika dalam MEA perusahaan asing dapat masuk, kemungkinan besar pekerja yang terdapat di UMKM akan bertransmigrasi ke perusahaan asing yang mampu memberikan tingkat kesejahteraan yang lebih maksimal. Sebenarnya disinilah dibutuhkan peran dana pensiun agar mampu 
masuk ke golongan UMKM untuk menghindari transmigrasi sumber daya manusia tersebut.

Perlu revolusi dan inovasi terhadap dunia lembaga keuangan non perbankan terutama dana pensiun agar kinerja semakin optimal serta tidak lupa diperlukan formulasi yang tepat sehingga dapat memberikan sumbangan yang maksimal terhadap pertumbuhan perekonomian dan kesejahteraan bangsa. Dengan semakin maju dan berkembanganya dana pensiun maka manfaatnya tentu saja tidak dirasakan oleh para pekerja saja akan tetapi nantinya juga pasti akan dirasakan oleh Usah Mikro Kecil Menengah pada saat mengahadapi MEA

\section{METODELOGI PENELITIAN}

Penelitian ini menggunakan metode narasi deskriptif. Metode penelitian deskriptif adalah sebuah metode yang digunakan untuk mendeskripsikan,

menginterpretasikan sesuatu fenomena, misalnya kondisi atau hubungan yang ada, pendapat yang berkembang, dengan menggunakan prosedur ilmiah untuk menjawab masalah secara aktual. Dengan demikian, peneliti beranggapan bahwa metode penelitian deskriptif sesuai dengan penelitian yang dilaksanakan oleh peneliti. Data yang digunakan merupakan data skunder yang diperoleh dari berbagai sumber terutama dari Otoritas Jasa Keuangan (OJK) mengenai Statistik 2013 dan Direktori 2014 Dana Pensiun.

\section{PEMBAHASAN}

Dana pensiun dan asuransi merupakan salah satu lembaga keuangan non perbankan yang diharapkan mampu untuk menggenjot pertumbuhan perekonomian dan kesejahteraan masyarakat Indonesia. Seiring dengan majunya zaman, semakin tingginya peradaban serta semakin berkembangnya pola pikir masyarakat yang semakin maju dan peduli akan tingkat kesejahteraan sekarang dan masa depan pada perkembangannya dana pensiun mulai memiliki peranan sentral dalam memajukan kesejahteraan masyarakat.

Dana pensiun memang memiliki pertumbuhan yang lambat akan tetapi semakin tahun lembaga 
ini mulai mendapatkan perhatian dari masyarakat Indonesia. Agar lembaga ini memiliki proporsi peran yang lebih besar dan efek yang positif bagi pertumbuhan dan tingkat kesejahteraan bangsa, maka perlu beberapa solusi percepatan agar mampu meningkatkan pertumbuhan lembaga ini serta berusaha memangkas beberapa permasalahan yang terdapat di dalamnya.

\subsection{PERKEMBANGAN DANA}

\section{PENSIUN DI INDONESIA}

Ketika berbicara dana pensiun terutama di negara sedang berkembang seperti kawasan Asia Tenggara memang cukup rumit dan sulit. Hal ini wajar terjadi karena ketika berbicara dana pensiun maka akan banyak sekali institusi yang akan terlibat di dalamnya, bukan hanya berbicara masalah ekonomi yang mengatur kesejahteraan peserta dana pensiun saja, akan tetapi lebih dari itu juga berbicara masalah hukum yang nantinya mengatur mekanisme aturan yang akan diterapkan dalam dana pensiun. Keterbatasan pengertian mengenai dana pensiun dan inovasi yang terdapat dalam produk dana pensiun merupakan permasalahan yang harus dipecahkan di negara sedang berkembang termasuk Indonesia.

Perkembangan jumlah peserta dan lembaga keuangan dana pensiun terutama DPPK sudah sewajarnya bertambah mengikuti banyaknya industri yang terdapat di suatu negara dengan semakin banyaknya jumlah tenaga kerja yang terserap. Akan tetapi pada kenyataan di lapangan, perekembangan dana pensiun mulai dari tahun 2009 - 2013 stagnan dan cenderung mengalami penurunan.

Tabel 2 : Jumlah Peserta Dana Pensiun 2009 - 2013.

\begin{tabular}{llllll}
\hline Tahun & $\mathbf{2 0 0 9}$ & $\mathbf{2 0 1 0}$ & $\mathbf{2 0 1 1}$ & $\mathbf{2 0 1 2}$ & $\mathbf{2 0 1 3}$ \\
\hline \multicolumn{2}{l}{ Akumulasi Peralihan Progam Dana Pensiun } & & & \\
\hline DPPK PPMK ke DPPK PPIP & 9 & 9 & 10 & 11 & 13 \\
\hline Dana Pensiun yang Masih Aktif & & & & \\
\hline DPPK PPMP & 210 & 208 & 204 & 201 & 198 \\
\hline DPPK PPIP & 41 & 40 & 41 & 43 & 43 \\
\hline DPLK & 25 & 24 & 25 & 25 & 24 \\
\hline Jumlah & 276 & 272 & 270 & 269 & 265 \\
\hline
\end{tabular}

Sumber : Buku Statistik 2013 dan Direktori 2014 Dana Pensiun (OJK). 
Pada tahun 2009 - 2013 jumlah pengelola dana pensiun semakin kecil baik diihat dari DPPK dan DPLK. Ada beberapa alasan yang mendasari mengapa dana pensiun di Indonesia mengalami pembubaran diantaranya masalah efisiensi, perubahan progam pensiun, perusahaan bubar atau akuisisi/ merger, masalah kesulitan keuangan pendiri. Dimana dari permasalahan yang terdapat di atas, masalah yang paling dominan dari pembubaran dana pensiun adalah pertama mulai beralihnya pengguna dari DPPK ke DPLK kemudian permasalahan kedua kesulitan keuangan yang dialami oleh pendiri.

Dari sisi pengelola memang harus diakui permasalahan terbesarnya adalah bagaimana cara mengolah dana pensiun itu agar nantinya memberikan manfaat kepada kedua belah pihak baik kepada lembaga ataupun peserta dana pensiun. Selama ini dana pensiun lebih banyak diputar pada kegiatan - kegiatan penyertaan saham dan pasar - pasar keuangan lainnya dimana resiko yang dihadapi juga pasti jauh lebih besar, sedangkan pembiayan riil yang melibatkan peran dana pensiun di Indonesia masih terhitung kecil. Ketika ingin mewujudkan pembangunan yang sebenarnya dan pembangunan yang berkelanjutan haruslah sangat memperhatikan sektor riil.

\section{Gambar 1 :Alasan Pembubaran Dana Pensiun.}

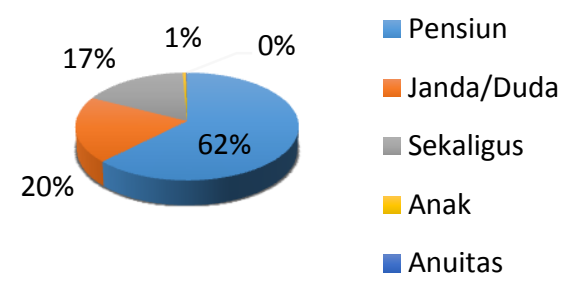

Sumber : Buku Statistik 2013 dan Direktori 2014 Dana Pensiun (OJK)

Sedangkan ketika melihat perkembangan dana pensiun dari pesertanya ternyata telah terjadi peningkatan. Jumlah peserta DPPK dan DPLK pada tahun 2013 mengalami kenaikan sebebsar 8,60\% terdapat beberapa indikator penyebab terjadinya kenaikan jumlah peserta pertama dalah dimana para perusahaan mulai mewajibkan dan mengharus para tenaga kerjanya mengikuti progam dana pensiun yang telah tersedia, sedangkan penyebab kedua adalah mulai mengerti dan pahamnya warga masyarakat tentang arti penting dana pensiun. Anggapan 
sementara dapat dikatan naiknya peserta dana pensiun diakibarkan oleh para perusahaan mulai mewajibkan dan mengharuskan para tenaga kerjanya mengikuti progam dana pensiun yang telah tersedia.

Pertumbuhan populasi

Indonesia saat ini masuk dalam negara yang memiliki jumlah penduduk terbanyak di dunia. Dengan banyaknya jumlah penduduk yang tersebar di Indonesia maka jumlah tenaga kerja yang dimiliki juga cukup melimpah. Tenaga kerja yang cukup banyak pada beberapa tahun ini akan menyebabkan masalah kejahteraan ekonomi di kemudian hari karena pada beberapa tahun mendatang sudah dapat dipastikan tenaga kerja saat ini akan memasuki usia tidak produktif. Dibutuhkan suatu lembaga yang mampu menangani masalah ini, dimana lembaga tersebut adalah lembaga keuangan non perbankan dana pensiun.

Pengolahan dan pensiun di Indonesia harus dilakukan secara benar dan tepat, mengingat proyeksi pada tahun 2050, usia pensiun penduduk Indonesia cukup tinggi. Ketika para pekerja usia pensiun ini membanjiri populasi Indonesia untuk beberapa tahun kedepannya pasti akan menjadi masalah besar bagi Indonesia ketika tingkat kesejahteraan tenaga kerja tidak diperhatikan sejak dini. Dana pensiun dianggap mampu mengendalikan tingkat kesejahteraan para pekerja melalui progam pensiun yang ditawarakan. Dimana para pekerja memiliki kewajiban untuk menabung sebagian dana dari pendapatannya untuk menikmati hasil nantinya di usia pensiun.

Gambar 2: Proyeksi Penduduk Berusia Di Atas 65 Sebagai Persentase Dari Tenaga Kerja Usia (15-64), Proyeksi PBB 


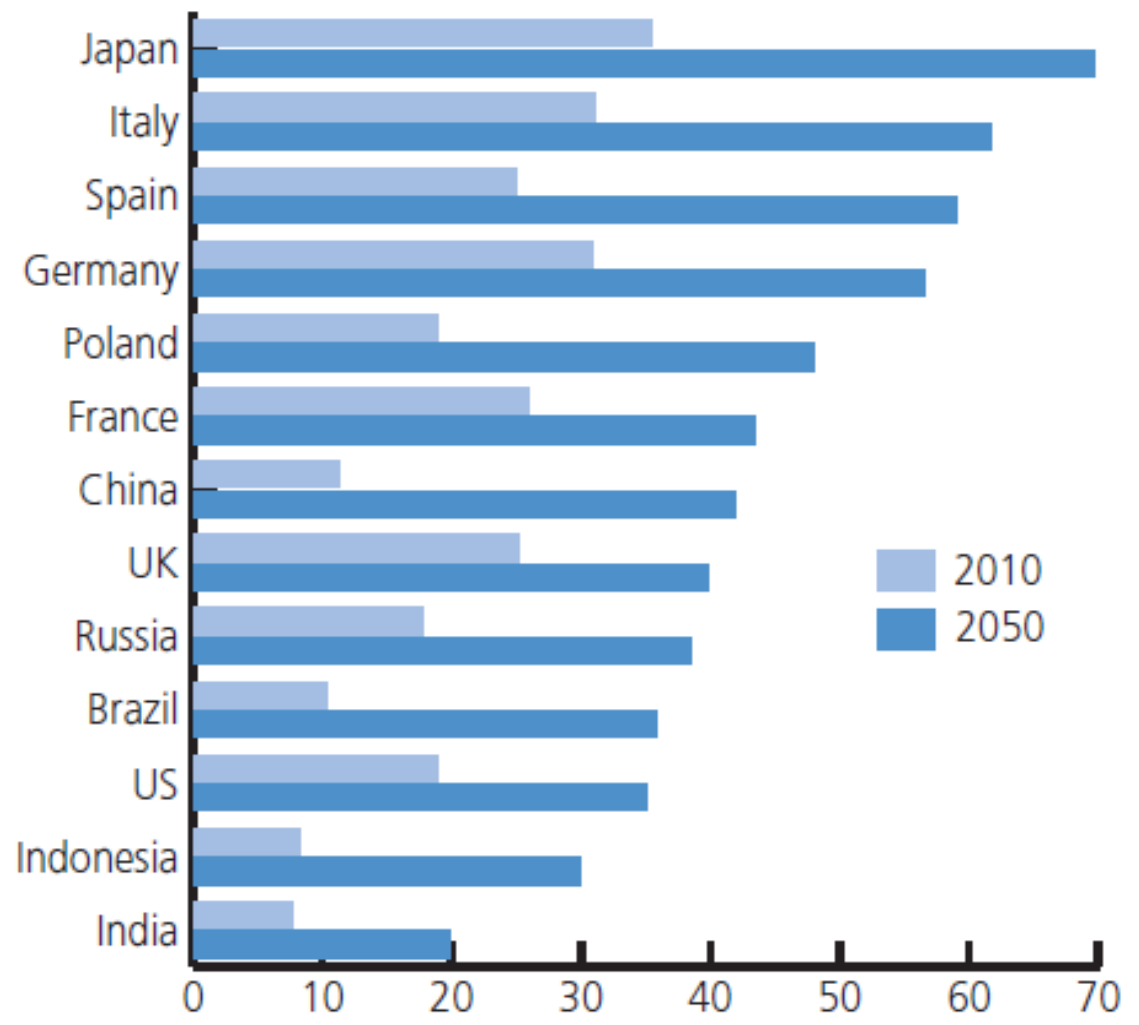

Sumber : Defisi Populasi PBB, World Population Prospect : 2010

\section{PERMASALAHAN}

Sebenarnya ada dua pokok permasalahan yang sudah mendarah daging pada lembaga non keuangan dana pensiun, masalah pertama pelaku, baik itu dilihat dari lembaga penyelenggara ataupun peserta, kemudian masalah yang kedua variasi dan inovasi dari produk yang ditawarkan.

Pertama, apabila dilihat dari pelaku baik itu dari lembaga dan peserta pensiun. Ketika mendengar dana pensiun yang pertama kali terlintas di mainseat orang Indonesia adalah hampir semua peserta adalah para pensiunan yang sudah memasuki usia senja, dimana dana pensiun biasanya memiliki fungsi utama untuk memenuhi kebutuhan pokok. Hal ini tampak jelas pada tahun 2013 dimana lebih dari 65\% dana pensiun didominasi oleh para pensiunan yang bisa dikatakan sudah tidak dalam usia produktif.

Dewasa ini pertumbuhan dana pensiun mungkin sudah merambah ke tenaga kerja yang tersebar dalam perusahaan - perusahaan besar. Akan tetapi penyebaran dan pertumbuhan 
dana pensiun yang terdapat pada perusahaan ini bisa dikatakan bukan secara murni karena pekerja menginginkannya, akan tetapi biasanya para pekerja mengikuti dana pensiun ini karena sudah termasuk dari kebijakan perusahaan itu sendiri yang mewajibkan para pekerjanya mengikuti progam pensiunan.

Tabel 3 : Penetrasi Peserta Dana Pensiun Tahun 2009 - 2013.

\begin{tabular}{|c|c|c|c|c|c|}
\hline & 2009 & 2010 & 2011 & 2012 & 2013 \\
\hline Jumlah tenaga kerja* & 52.691 .899 & 56.813 .952 & 60.905 .202 & 62.605 .346 & 64.192 .990 \\
\hline $\begin{array}{l}\text { Jumlah peserta dana } \\
\text { pensiun }\end{array}$ & 2.681 .233 & 2.817 .997 & 3.082 .708 & 3.345 .798 & 3.633 .645 \\
\hline Penetrasi & $5.09 \%$ & $4.96 \%$ & $5.06 \%$ & $5.34 \%$ & $5.66 \%$ \\
\hline
\end{tabular}

*tenaga kerja yang berusaha sendiri, berusaha dengan buruh tetap, dan buruh/karyawan/pegawai

Sumber : Buku Statistik 2013 dan Direktori 2014 Dana Pensiun (OJK)

\section{Gambar 3 :Komposisi Penerimaan Manfaat Pensiun 2013.}

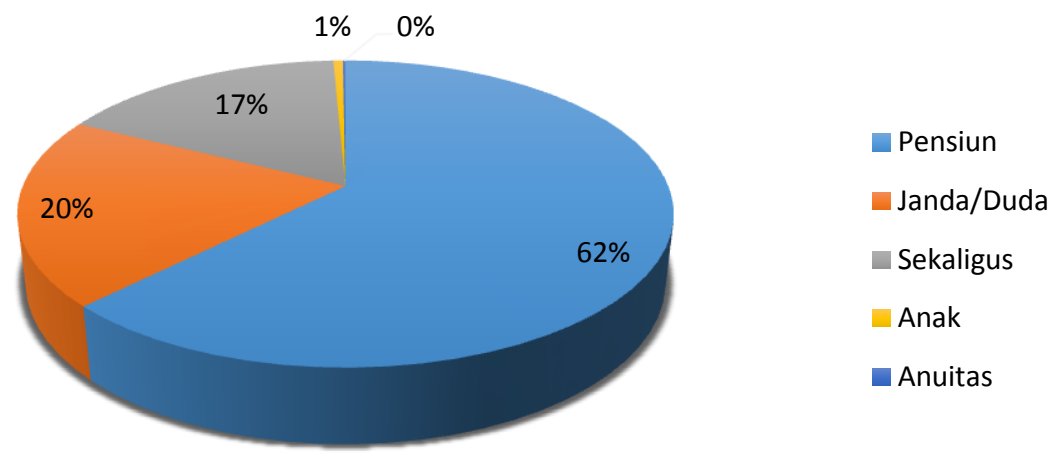

Sumber : Buku Statistik 2013 dan Direktori 2014 Dana Pensiun (OJK)

Permasalahan pertama

mengenai pelaku dana pensiun secara ringkas dapat dibedakan menjadi dua bagian utama. Dana pensiun sudah seharusnya bukan lagi dimanfaatkan hanya oleh para pensiunan seperti paradigma lama yang sudah kita ketahui bersama. Sedangkan bagian 
kedua adalah walaupun dana pensiun dewasa ini sudah merambah ke tenaga kerja, akan tetapi pada dasaranya hanya pada tenaga kerja yang biasa hanya terdapat pada perusahaan besar yang berskala nasional atau multinasional, sedangkan para pekerja yang terdapat pada industri atau perusahaan yang berskala kecil menengah sebagian besar masih belum mendaftarakan pekerjanya untuk mengikuti progam pensiun, padahal sudah bukan menjadi rahasia umum bahwa sebagian besar pekerja Indonesia bekerja pada perusahaan berskala kecil dan mengengah. Hal ini bisa dilihat dari $100 \%$ pekerja Indonesia, hanya masih sekitar $5,66 \%$ yang melakukan dan menjadi peserta progam pensiun.

\section{Gambar 4 : Jumlah Peserta Dana Pensiun Terhadap Total Jumlah Tenaga Kerja Tahun 2013.}

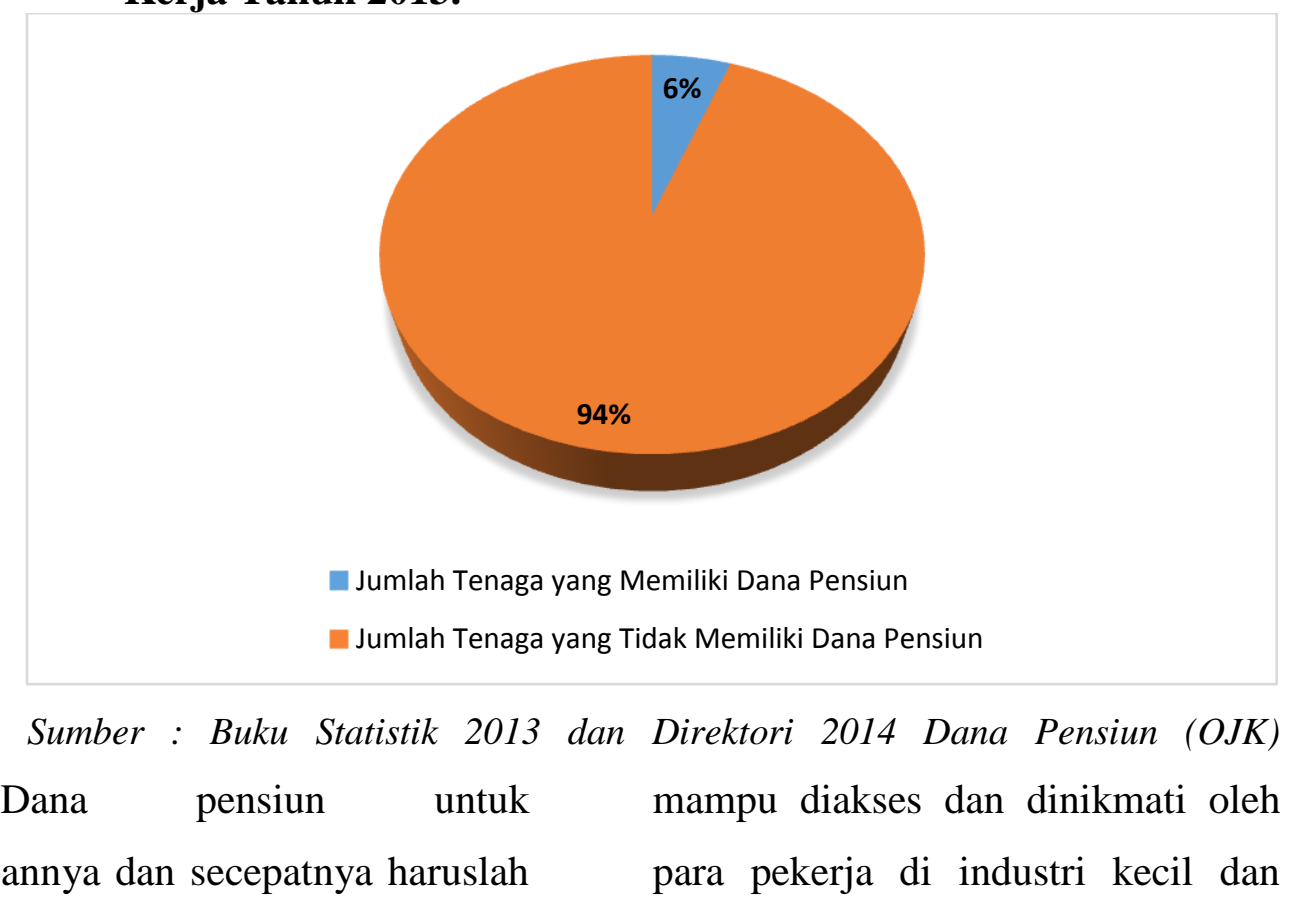

kedepannya dan secepatnya haruslah para pekerja di industri kecil dan 
menengah serta yang jauh lebih penting dari itu kesadaran mengenai arti penting dari dana pensiun bagi setiap pekerja bukan hanya prasyarat bagi setiap perusahaan terhadap para pekerjanya yang selama ini terjadi.

Dana pensiun sesuai dengan undang - undang nomor 11 tahun 1992 adalah badan hukum yang mengelola dan menjalankan progam yang menjanjikan manfaat pensiun bagi pesertanya. Defisnisi tersebut memberikan pengetian bahwa dana pensiun merupakan suatu lembaga yang mengelola progam pensiun yang dimaksudkan untuk memberikan kesejahteraan kepada karyawan suatu perusahaan terutama yang telah pensiun. Penyelenggarakaan pensiun tersbut dapat dikelola oleh pemberi kerja atau dengan menyerahkan kepada lembaga - lembaga keuangan yang menawarkan jasa pengolahan progam pensiun. (Triandaru : 2006).

Melihat dari pengertian dana pensiun diatas menurut UU no 11 tahun 1992 nampak jelas bahwa penggunaan dana pensiun dikhususkan kepada para pelaku atau peserta dana pesiun dimana masa penggunaannya berlangsung pada saat si pelaku sudah tidak bekerja dan berada dalam masa waktu pensiun.

Dalam UU telah dijelaskan bahwa penerima manfaat adalah para pelaku dana pensiun dan bahayanya hampir setip dana pensiun sebenarnya sebagian besar dialokasi untuk memenuhi kebutuhan sehari hari yang notabe-nya adalah kegiatan konsumtif. Dilihat dari segi penggunanya juga, kebanyakan dana pensiun digunakan dan dapat dinikmati oleh para pensiunan yang sudah tidak produktif di usia kerja. Ini sebenarnya alasan utama mengapa dana pensiun tidak dapat berkembang, dimana para pengguna adalah para pensiun yang sudah tidak dalam usia produktif dan pemanfaatannya lebih banyak digunakan untuk kegiatan konsumtif.

Harus diakui juga sebenarnya, ketika berbicara siapakah yang paling banyak mendapatkan manfaat dari adanya dana pensiun? Selama ini yang memiliki manfaat terbanyak dari dana pensiun adalah lembaga keuangan yang mengolah dana pensiun itu sendiri kemudian barulah para peserta dana pensiun. Padahal ketika berbicara secara logika 
pemanfaatan dana pensiun sudah seharusnya harus diterima secara maksimal oleh pengguna atau peserta kemudian baru diturunkan kepada anggota keluaraga yang ingin menggunakan dana tersebut.

Permasalahan kedua dari dana pensiun adalah hampir sama persis dengan lembaga keuangan non bank yan lain adalah minimnya inovasi produk - produk yang ditawarkan. Produk dana pensiun selama ini sebagian besar dari penggunanya hanya memanfaatkan sebagai persiapan ketika mereka sudah tidak bekerja atau dikatakan tidak produktif lagi sehingga dana pensiun yang dikumpulkan dapat digunakan untuk menunjang kehidupan sehari hari nantinya. Pengertian dana pensiun dalam arti luas sekarang dapat juga dapat diartikan sebagai sarana media investasi yang mana pesertanya tidak terfokus pada pemanfaatan akhir untuk usia pensiun. Akan tetapi pemanfaatan dana pensiun sebagai media investasi yang nantinya biasanya menuju kepada saham sebagaian besar hanya dimanfaatkan oleh para pelaku yang memiliki jumlah aset dana pensiun yang dalam jumlah yang besar, selain itu pada kenyataan ketika dana dunia pensiun banyak dimanfaatkan untuk aktivitas saham yang sebagian besar penikmat keuntungan adalah pihak pengolah dana yang tidak lain adalah perusahaan itu sendiri dan pemilik dana pensiun yang terlebih yang memiliki jumlah aset menengah keatas yang bisa menikmati manfaatnya secara nyata.

Ketika pemanfaatan dan nilai guna dana pensiun hanya difokuskan kepada para pekerja yang sedang memasuki usia pensiun, terkena cacat atau keluaraga saja maka sudah dapat dipastikan bahwa percepatan pertumbuhan lembaga keuangan dana pensiun tidak akan terwujud, karena pada dasarnya dana pensiun yang terkumpul hanya akan digunakan untuk kebutuhan konsumtif saja nantinya. Sudah seharusnya penggunaan dana pensiun dapat disalurkan kepada tindakan tindakan yang produktif akan tetapi tanpa mengabaikan esensi dasar dari dana pensiun itu sendiri.

Masih rendahnya inovasi penggunaan dari dana pensiun juga menjadikan salah satu penyebab kurang berkembangnya dana pensiun. Hanya terdapat dua 
pengertian mengenai dana pensiun yang terdapat di Indonesia, dimana semua masyarakat menganggap dana pensiun adalah tabungan untuk hari tua dan penggunanya adalah individu yang telah mengikuti progam tersebut. Seperti telah dibahas sebelumnya juga dana pensiun merupakan dana yang sebagian besar nantinya digunakan untuk keperluan konsumtif yang notabenya sedikit sekali unsur produktifitasnya.

\section{Hubungan Antara Dana Pensiun,} Masyarakat Ekonomi Asean Dan

\section{Eksistensi UMKM}

Pekerja akan berusaha mencari tingkat kesejahteraan yang paling tinggi, sudah barang tentu ketika berbicara kesejahteraan tentu saja berkaitan pula dengan tempat dimana dia bekerja. Pekerja akan berbondong - bondong menuju ke perusahaan yang mampu memberikan tingkat kesejahteraan tertinggi. Dewasa ini tingkat kesejahteraan tertinggi tidak saja diukur mutlak dengan menggunakan tingkat gaji yang diberikan. Akan tetapi terdapat variabel pendukung lainnya yang tidak kalah penting yaitu fasilitas yang di dapatkan oleh para pekerja. Salah satu variabel pendukung yang banyak dilirik oleh para pekerja adalah ketersediannya progam dana pensiun.

Perusahaan yang mampu memberikan fasilitas maksimum bagi para pekerja maka secara tidak langsung perusahaan tersebut mampu menarik para tenaga kerja untuk bekerja dalam perusahaannya. Salah satu cara untuk menarik para tenaga kerja adalah dengan memberikan layanan atau progam dana pensiun. Dengan adanya progam dana pensiun yang dimiliki perusahaan maka dapat dikatakan paling tidak tingkat kesejahteraan para tenaga kerja di hari tua nantinya bisa terjamin.

Permasalahan yang muncul di Indonesia tidak semua perusahaan memiliki progam dana pensiun bagi para pekerjanya, terlebih bagi perusahaan yang tingkat usahanya masih skala kecil dan menengah. Bisa dikatakan tingkat kesejahteraan pekerja masih rendah pada perusahaan kecil dan menengah. Untuk sekarang mungkin perusahaan kecil dan menengah tidak terlalu fokus tentang dana pensiun yang seharusnya dimiliki oleh tenaga kerjanya, mungkin yang menjadi 
priorotas utamanya adalah bagaimana meningkatkan gaji tenaga kerja. Akan tetapi dengan semakin berkembangnya zaman tentu saja ukuran kesejahteraan seorang tenaga kerja tidak hanya dilihat dari berapa gaji yang mereka dapatkan akan tetapi juga pastinya akan melihat berapakah tabungan yang dapat disisihkan ketika mereka sudah tidak lagi bekerja, dimana pertanyaan pertanyaan seperti itu bisa terjawab dengan adanya progam dana pensiun.

MEA merupakan suatu kawasan ekonomi dimana semua tenaga kerja dan seluruh perusahaan diberikan kebebasan untuk bergerak demi mencapai keuntungan tertinggi yang di harapkan. Untuk kasus tenaga kerja seperti telah dikatakan sebelumnya jelas mencari tingkat kesejahteraan tertinggi, dengan adanya MEA besar kemungkinan perusahaan kecil dan menengah sedikit banyak akan mulai kehilangan tenaga kerja mereka. Hal ini dirasakan wajar karena para tenaga kerja kan berusaha mencari perusahaan yang mampu menyejahterakan mereka secara optimal, baik dalam bentuk upah yang jauh lebih tinggi ataupun fasilitas seperti dana pensiun.

Sudah bukan menjadi rahasia umum lagi bagi bangsa Indonesia bahwa kualitas perusahaan asing dalam memberikan fasilitas dan upah kepada para pekerja jauh lebih bagus dan dirasa lebih menyejahterakan pekerjanya. Permasalahan kronis yang mungkin akan muncul pada saat MEA ketika melihat dari sudut pandang para kerja adalah, ditakutkan terjadinya mobilisasi pekerja UMKM yang terdapat di Indonesia akan berpindah kepada perusahaan besar asing. Ketika hal tersebut terjadi maka UMKM pasti akan kehilangan banyak tenaga kerja dimana nantinya tentu saja proses produksi akan terganggu hingga sampai pada output yang dihasilkan tidak akan maksimal. Tentu saja hal ini akan sangat menganggu eksistensi UMKM yang selama ini sudah terbentuk. Tentu dibutuhkan setidaknya pengikat untuk tetap menjaga agar para pekerja pada perusahaan kecil dan menengah nantinya tidak melakukan mobilisasai ke perusahaan asing akibat adanya MEA, salah satu yang mampu mengikat para tenaga kerja 
agar tetap bertahan kepada UMKM adalah dengan adanya dana pensiun.

\section{Solusi Yang Ditawarkan}

Seperti yang dikemukakan di atas bahwa permasalahan pertama dari dana pensiun adalah mengenai para penggunanya, dimana para pengguna dana pensiun sebagian besar adalah para pekerja akan tetapi sayangnya para pekerja yang menggunakan dan menikmati dana pensiun hanya para pekerja yang sebagian besar berasal dari perusahaan - perusahaan besar dan para pekerja yang bekerja di instansi pemerintahan.

Dari permasalahan ini, tenaga kerja terkesan terbagi menjadi dua dimensi, dimana mereka yang bekerja di perusahaan besar dan instansi pemerintah maka sudah dipastikan dapat menikmati dan mengakses dana pensiun akan tetapi bagi para pekerja yang memreka bekerja pada industri kecil dan menengah, masih sangat minim akses dalam penggunaan dana pensiun. Ketika hal tersebut tetap dipertahakan maka mimpi untuk tenaga kerja yang menginginkan kehidupan yang sejahtera dan layak di akhir usia produktif mereka akan bersifat khayalan semu belaka.

Solusi yang mengkin bisa ditawarkan dari adanya permasalahan pertama adalah, minimal sebelum memasuki Masyarakat Ekonomi Asia 2015 semua perusahaan berskala kecil, menegah atau besar harus mewajibkan semua tenaga kerjanya memiliki dana pensiun. Kewajiban ini tentunya harus dipatuhi oleh setiap perusahaan yang memperkerjakan tenaga kerja di dalam proses produksinya. Walaupun dirasa kebijakan ini terkesan memaksa akan tetapi akan berdampak besar bagi kelangsungan pekerja dan perekonomian usaha kecil dan menengah di masa yang akan datang.

Apabila dilihat keuntungan kebijakan ini dari sisi pekerja adalah (i) para tenaga kerja akan memiliki tabungan untuk hari tuanya disaat mereka tidak lagi dalam usia produktif sehingga tingkat kesejahteraan pekerja dapat terangkat baik dalam perusahaan kecil sekalipun. (ii) masyarakat akan berusaha dan wajib mengerti dengan sendirinya tentang manfaat 
sebenarnya dari adanya dana pensiun karena bahwa salah satu ciri dari tenaga kerja bangsa Indonesia mengenai dana pensiun adalah kebanyakan dari mereka akan lebih memprioritasakan kenaikan gaji dari memperhatikan dana pensiun untuk kehidupan di kemudian hari kelak.

Sedangkan ketika berbicara mengenai pemanfaatan dana pensiun selama ini secara garis besar yang dapat memanfaatkan dana pensiun ada para peserta yang pemanfaatannnya bisa dinikmati pada saat usia pensiun dan lembaga keuangan yang mengolahnya. Ketika hal ini tetap berlanjut maka tujuan terbesar dari kegunaan dana pensiun adalah untuk kegiatan konsumtif belaka. Hal ini setidaknya harus dirubah dimana agar dana pensiun dapat dimanfaatkan menjadi dana yang sifatnya lebih produktif. Sebenarnya pemanfaatan dana pensiun untuk kegiatan produktif sudah terlaksana dalam kegiatan penanaman investasi kepada pasar saham atau obligasi.

Penanaman melalui investasi dan obligasi memang dapat menggenjot pertumbuhan sektor keuangan akan tetapi pertumbuhan yang berekelanjutan dan pertumbuhan yang sebenarnya adalah pertumbuhan yang mampu menggenjot sektor riil. Sudah seharusnya dana pensiun dapat dimanfaatkan untuk menggenjot pertumbuhan riil dan menciptkana lapangan pekerjaan yang baru bagi para anggota dana pensiun beserta keluarganya. Dana pensiun seharusnya dapat digunakan untuk pendiriaan usaha bagi para anggota keluarga dana pensiun. Dengan demikian dana pensiun tidak hanya bersifat untuk tabungan di hari tua saja akan tetapi dapat digunakan sebagai sarana tempat peminjaman modal bagi para keluarga peserta dana pensiun untuk mendirikan sebuah lapangan usaha yang baru. Tentu saja dalam pelaksanaan haruslah diawasi sama seperti apa yang telah dilakukan lembaga lembaga keuangan pada umumnya.

Pengembangan fungsi dana pensiun seperti yang telah dijelaskan di atas cukup beralasan karena Indonesia merupakan negara komunal, yaitu sebuah sistem yang mendasarkan atas kebudayaan bersama, gotong royong atau gemein schaaft, sehingga sistem kekerabatan 
dan hubungan antara satu anggota keluarga dengan anggota keluarga lainnya tergolong dekat. Kekerabatan juga tercermin pada saat antara mantan karyawan memasuki usia pensiun sebagian besar adalah orang yang sudah pensiun kemudoan hidup dengan anak - anak meraka dan keluarganya. Hal ini mengimplikasikan bahwa anak tersebut juga bertanggung jawab untuk menanggung biaya hidup orang tua mereka, baik secara independen oleh satu anak yang sudah sukses/ mapan, atau secara bersamaan dengan sistem patungan antara beberapa anak. (Satiti : 2015).

Dari sini akan semakin jelas bahwa sesungguhnya penggunaan dana pensiun yang benar dewasa ini tidak hanya harus difokuskan kepada tabungan di hari tua bagi para pekerja akan tetapi pensiun seharusnya bisa dimanfataakan oleh para sanak keluaraga pekerja untuk menciptakan kegiatan usaha yang lebih produktif sehingga nantinya tentu saja tingkat kesejahteraan pekerja akan lebih terjamin karena diharapakan ketika sudah mulai memasuki usia pensiun para tenaga kerja tetap mendapatkan penghasilan yang sudah dirintis oleh anggota keluarganya melalui penggunaan dana pensiun untuk aktifitas seperti kewirausahaan.

\section{KESIMPULAN}

Dana pensiun merupakan lembaga non keuangan yang yang memiliki peran penting dalam menentukan tingkat kesejahteraan tenaga kerja pada masa pensiun. Dewasa ini peran dana pensiun diharapkan mampu meningkat kesejahteraan bukan hanya peserta akan tetapi juga anggota keluarga yang ditanggungnya. Dana pensiun diharapkan mampu berfungsi dan dapat digunakan tidak hanya pada masa pensiun dan hanya dapat digunakan oleh peserta akan tetapi diharapkan dana pensiun mampu digunakan oleh anggota kelaurga yang bersangkutan untuk keperluan modal usaha sehingga manfaat dana pensiun lebih terasa bersifat produktif dan bukan hanya digunakan sebagai dana untuk kebutuhan hidup di masa tua.

Terdapat dua pokok permasalahan yang sudah mendarah daging pada lembaga non keuangan dana pensiun, masalah pertama 
pelaku, baik itu dilihat dari lembaga penyelenggara ataupun peserta, kemudian masalah yang kedua variasi dan inovasi dari produk yang ditawarkan. Ketika dilihat dari peserta, kebanyakan peserta asuransi adalah berasal dari perusahaan berskala besar dan pegawai negari sipil (PNS), sedangkan perusahaan sekaliber UMKM masih jarang sekali memiliki tenaga kerja yang mendaftarkan dirinya ke progam dana pensiun. Hal yang tentunya ditakutkan nantinya adalah ketika para tenaga kerja memasuki usia pensiun maka tentu saja akan mempengaruhi tingkat kesejahteraan yang berujung kepada pertumbuhan perekonomian dan tingkat kemiskinan yang semakin memburuk.

Permasalahan kedua, dimana masih minimnya inovasi yang terdapat dalam progam dana pensiun. Sebagian besar dana pensiun hanya bisa dimanfaatkan ketika yang bersangkutan memasuki usia pensiun. Ketika hal ini tetap berlangsung, maka pengembangan dana pensiun hanya akan terfokus pada pemenuhan kebutuhan pada masa pensiun yang hanya bersifat konsumtif belaka. Dana pensiun seharusnya haruslah dapat dimanfaatkan untuk kegiatan produktif seperti pendirian modal usaha yang lebih produktif dan penggunanya boleh berasal dari keluarga peserta asuransi yang masih produktif, dengan demikian dana pensiun bukan hanya dapat meningkatkan kesejahteraan tetapi juga mampu mempercepat pertumbuhan dan kestabilan perekonomian.

Sudah seharusnya semua industri yang terdapat di Indonesia baik itu skala kecil, menegah atau besar memperhatikan kesejahteraan tenaga kerjanya secara penuh. Untuk meningkatkan kesejahteraan tenaga kerja salah satunya adalah melalui dana pensiun. Usaha mikro secara khusus dalam beberapa tahun terakhir harus segera berbenah mengenai dana pensiun, sudah seharusnya semua pekerja UMKM memiliki dana pensiun yang mampu menjamin masa tua pekerja. Tenaga kerja akan berusaha mencari tingkat kesejahteraan tertinggi. MEA merupakan tantangan bagi UMKM, 
bukan hanya dilihat dari tingkat persaiangn saja akan tetapi dikhawatirkan ketika memasuki MEA akan banyak tenaga kerja yang akan melakukan mobilisasi menuju perusahaan asing untuk mencari tingkat kesejahteraan yang paling tinggi. Ketiak hal ini terjadi maka dikhawatirkan eksistensi UMKM akan tertaganggu baik dalam hal persaingan barang dan jasa yang ditawarkan, skala produksi hingga mobilitas tenaga kerja yang menginginkan kesejahteraan yang jauh lebih bagus.

\section{DAFTAR PUSTAKA}

Guerard, Yves. 2012. Pension systems in East and Southeast Asia: Promoting fairness and sustainability. Mandaluyong City, Philippines: Asian Development Bank.

Chan-Lau, Jorge A. 2004. Pension Funds and Emerging Markets. IMF Working Paper

Otoritas Jasa Keuangan (OJK). 2015. Ikhtisar Data Keuangan Dana Pensiun Januari - April 2015. Jakarta.
Otoritas Jasa Keuangan (OJK). 2015. Ikhtisar Data Keuangan Dana Pensiun Januari - Desember 2014. Jakarta.

Otoritas Jasa Keuangan (OJK). 2014. Ikhtisar Data Keuangan Dana Pensiun Januari - November 2014. Jakarta.

Otoritas Jasa Keuangan (OJK). 2014. Buku Statistik 2013 dan Direktori 2014 Dana Pensiun. Jakarta.

Satiti, Novita Ratna. 2015. Membangun Ekonomi Nasional yang Kokoh, Kajian dan Pengalaman Empirik. UMM Press. Malang.

Tan Wai Kuen. 2014. Time for Asian

Pension Systems to Take Center Stage. Fung Global Institute

Triandaru, Sigit dan Totok Budisantoso. 2006. Bank dan Lembaga Keuangan Lain Edisi 2. Salemba Empat. Jakarta.

OECD. 2009. Pensions at Glance Special Edition : Asia/ Pacific. Wold Bank 